overestimated, it is still a real threat, as are other bloodborne viruses for which no vaccine is available.

On these grounds, we find it wise to adopt these changes in surgical technique and choreography, especially for the coming generations of surgeons. These measures will reduce the risk of occupational acquisition of HIV and other bloodborne pathogens, especially hepatitis B virus and hepatitis $\mathrm{C}$ virus, which are of greater risk to the surgeon.

\section{REFERENCES}

1. Statens Seruminstitute. Epi-Nyt. 1995; uge 47.

2. Statens Seruminstitute, Epi-nyt, 1996; uge 12.

3. Heptonstall J, Porter K, Gill O. Occupational transmission of HIV. Public Health Laboratory Service 1995; report. December.

4. Hussain SA, Latif ABA, Choudhary AAAA. Risk to surgeons: a survey of accidental injuries during operations. $\mathrm{Br} J$ Surg 1988;75:314-316.

5. Tokars JI, Bell DM, Culver DH, et al. Percutaneous injuries during surgical procedures. JAMA 1992;267:2899-2904.

6. Lowenfels AB, Wormser GP, Jain R. Frequency of puncture injuries in surgeons and estimated risk of HIV infection. Arch Surg 1989;124:1284-1286.

7. McKinney WP, Young MJ. The cumulative probability of occupationally acquired HIV-infection: the risk of reported exposures during a surgical career. Infect Control Hosp Epidemiol 1990;11:243-247.
8. Raahave D, Bremmelgaard A. New operative technique to reduce surgeon's risk of HIV-infection. J Hosp Infect 1991;18(suppl A):177-183.

9. Gerberding JL, Littell C, Tarkington A, Brown A, Schecter WP. Risk of exposure of surgical personnel to patient's blood during surgery at San Francisco General Hospital. N Engl J Med 1990;322:1788-1793.

10. Centers for Disease Control. Guidelines for prevention of transmission of human immunodeficiency virus and hepatitis B virus to healthcare and public-safety workers. MMWR $1989 ; 38: 9-10$

11. Joint Working Party of the Hospital Infection Society and the Surgical Infection Study Group. Risks to surgeons and patients from HIV and hepatitis: guidelines on precautions and management of exposure to blood or body fluids. BMJ 1992;305:1337-1343.

12. Quebbeman EJ, Telforce GL, Wadsworth K, Hubbard S, Goodman H, Gottlieb MS. Double gloving. Protecting surgeons from blood contamination in the operating room. Arch Surg 1992;127:213-217.

13. Raahave D, Bremmelgaard A. AIDS/HIV: cumulative risk of surgeons-changes in surgical handicraft. Surg Res Comm 1990;7:161-168

14. Bessinger CD. Prevention transmission of human immunodeficiency virus during operations. Surg Gynecol Obstet 1988;167:287-289.

15. Mast S, Geberding JL. Factors predicting infectivity following needlestick exposure to HIV: an in vitro model. Clin Res 1991;39:58A.

\title{
Joint Commission's Blue Ribbon Panel to Evaluate Performance Measurement Systems
}

\section{Gina Pugliese, RN, MS Martin S. Favero, PhD Medical News Editors}

The Joint Commission Board of Commissioners recently approved the Council on Performance Measurement's recommendation to evaluate the more than 140 candidate performance measurement systems that have been submitted in consideration for potential use in the future accreditation process. This is part of an overall plan to integrate data from multiple qualified performance measurement systems into the accreditation process to assure the element of choice for each organization.

The Joint Commission believes that the use of performance data in accreditation will enhance the value of the accreditation process by providing objective data to support internal quality improvement activities; permit healthcare organizations the opportunity to demonstrate accountability to their patients, communities, and purchasers of health care; and provide the Joint Commission the means to link standards compliance with the measurement of actual performance.

The Joint Commission has developed progressive implementation requirements for six specific criteria that will require either immediate compliance in 1996 or in the future, before final approval of the measurement system. Measurement systems meeting the 1996 criteria will be recommended for initial approval and will be invited to work with the Joint Commission toward satisfying the identified future criteria. The six criteria are (1) performance measures and data elements; (2) database; (3) data quality; (4) risk adjustment/stratification for patient factors; (5) performance measure-related feedback; and (6) relevance for accreditation. Public comment is invited. A copy of the fulltext document containing additional details is available by calling the Joint Commission's Department of Research and Evaluation at 708-9165971.

FROM: Loeb JM, Buck AS. Framework for selection of performance measurement systems: attributes of conformance. JAMA 1996; 275(7):508. 